\title{
Life is art
}

\section{Poetry}

The way we do lifestyle

Is just beyond optsyle

We must bring optimal

To this type of windstyle

Eating resting working, all

Belong to aim serving all

Remove solely self and own

To go up of helping all

We must look for common goals

To make horse of coming foals

For speeding towards means

We must collect burning coals

You are all thoughts no body

Towards friends come buddy

Follow poems of the day

Keep your mind of corrody

When we begin work of arts

We must become full of arts

Life is arts and we artists

We must thus learn ways of arts. ${ }^{1-10}$

\section{Acknowledgments}

Thanks to the Ministry of Science Research and Technology, and National Elite Foundation for supporting the author's global initiatives and programs of optimizing science edification in the third millennium.

\section{Conflict of interest}

Author declares that there is no conflict of interest.
Special Issue - 2015

\section{Akbar Nikkhah}

Department of Animal Sciences, University of Zanjan, Iran

Correspondence: Akbar Nikkhah, Chief Highly Distinguished Professor, Department of Animal Sciences, Faculty of Agricultural Sciences, University of Zanjan, Foremost Principal Highly Distinguished Elite-Generating Scientist, National Elite Foundation, Iran, Email anikkha@yahoo.com

Received: November 18, 2015 | Published: November 25, 2015

\section{References}

1. Nikkhah A. Nutritional Wisdom. $J$ Nutr Health \& Food Engineer In Press. 2015.

2. Nikkhah A. Nutritional Chiefdom. J Nutr Health \& Food Engineer. 2015;2(5):00072.

3. Nikkhah A. Exercise into Size. J Nutr Health Food Eng. 2015;2(5):00071.

4. Nikkhah A. Nutritional Health: Pool \& Plunger. J Nutr Health Food Eng. 2015;2(5):00069.

5. Nikkhah A. Nutrition is Ambition. $J$ Nutr Health Food Eng. 2015;2(5):00068.

6. Nikkhah A. Arts, the Core of Sustainable Food and Agriculture: Brain Fruition. Adv Crop Sci Technol. 2015;3:e124.

7. Nikkhah A. Green Economy through Edification: Quality Life through Arts. J Glob Econ. 2014;2:e106.

8. Nikkhah A. Science Edification Arts: The Ultimate Frontiers to Eradicate Economic Sanctions. The Open Access Journal of Resistive Economics. 2013;1(1):1-6.

9. Nikkhah A. Science Education of the New Millennium: Mentorship Arts for Creative Lives. Creative Education. 2011;2(4):341-345.

10. Nikkhah A. Postmodern Academic Science Education: Mentorship Arts. Int J Acad Res Bus Soc Sci. 2010;1(3):91-95. 